\title{
Nitrogen metabolism and microbial production of dairy cows fed sugarcane and nitrogen compounds
}

\author{
Metabolismo do nitrogênio e produção microbiana de vacas leiteiras alimentadas com \\ cana-de-açúcar e compostos nitrogenados
}

\section{GONÇALVES, Geógenes da Silva ${ }^{1 *}$; PEDREIRA, Marcio dos Santos ${ }^{2}$; PEREIRA, Mara Lúcia Albuquerque ${ }^{1}$; SANTOS, Dimas Oliveira ${ }^{1}$; SOUZA, Dicastro Dias de ${ }^{3}$; PORTO JUNIOR, Antonio Ferraz ${ }^{3}$}

\footnotetext{
${ }^{1}$ Universidade Estadual do Sudoeste da Bahia, Programa de Pós-Graduação em Zootecnia, Itapetinga, Bahia, Brasil.

${ }^{2}$ Universidade Estadual do Sudoeste da Bahia, Departamento de Tecnologia Rural e Animal - UESB, Itapetinga, Bahia, Brasil.

${ }^{3}$ Universidade Estadual do Sudoeste da Bahia, Estudante de graduação em Zootecnia, Itapetinga, Bahia, Brasil.

*Endereço para correspondência: geoveterinario@hotmail.com
}

\section{SUMMARY}

The aim of this study was to evaluate the effect of dairy cow diets containing two different sources of urea on nitrogen metabolism and microbial synthesis. Eight crossbred cows were confined and distributed in two 4x4 Latin: FS - soybean meal (control), conventional urea (UC) 100\%; ULL 44 $\mathrm{UC}=56 \% / 44 \%$ ULL, ULL $88 \mathrm{UC}=12 \% / 88 \%$ ULL. Diets were offered to animals during 21 days with 14 days of adaptation. The $\mathrm{N}$ intake, retained nitrogen balance, nitrogen excretion in milk, urine, feces and total $\mathrm{N}$ excretion were similar and presented averages of $340.27 \mathrm{~g} /$ day, $136.73 \mathrm{~g} /$ day, $43.25 \mathrm{~g} /$ day, $\quad 53.17 \mathrm{~g} /$ day, $\quad 103.54 \mathrm{~g} /$ day, and $199.96 \mathrm{~g} /$ day, respectively. The percentages of urine and total nitrogen excretion were 16.24 and $60.71(\%)$, respectively. Ureic nitrogen in milk, urine and blood were $3.95 \mathrm{mg} / \mathrm{dL}, 4.32 \mathrm{mg} / \mathrm{dl}$ and $23.73 \mathrm{mg} / \mathrm{dL}$, respectively. The results found for the excretion of purine derivatives, allantoin, absorbable purines, microbial nitrogen, microbial protein and the relationship between microbial protein and digestible nutrients were $\quad 321.68 \mathrm{mmol} /$ day, $\quad 296.35 \mathrm{mmol} /$ day, $334.61 \mathrm{mmol} /$ day, $210.6 \mathrm{~g} /$ day, $1316.27 \mathrm{~g} /$ day, and $127.36 \mathrm{~g} / \mathrm{kg}$, respectively. The partial replacement of soybean meal by conventional urea and / or urea encapsulated in feeding lactating cows yielded similar results in nitrogenous compounds, the concentrations of nitrogen from urine and milk and microbial protein synthesis.

Keywords: coated urea, microbial production, nitrogen balance

\section{RESUMO}

Objetivou-se com este estudo, avaliar o efeito de duas diferentes fontes de ureia na dieta de vacas lactantes sobre o metabolismo de nitrogênio e produção de síntese microbiana. Utilizaram-se oito vacas mestiças holandêszebu confinadas distribuídas aleatoriamente em um delineamento em dois quadrados latino 4x4. FS - farelo de soja (controle); ureia convencional (UC) 100\%; ULL $44=\mathrm{UC} 56 \%$ / ULL $44 \%$; ULL $88=$ UC $12 \%$ / ULL $88 \%$. Os períodos experimentais foram de 21 dias, com 14 dias de adaptação. $\mathrm{O}$ consumo de nitrogênio, balanço de nitrogênio retido, excreções de nitrogênio no leite, na urina, nas fezes e total de $\mathrm{N}$ excretado foram semelhantes e apresentavam médias de 340,27g/dia; 136,73g/dia; 43,25g/dia; 53,17g/dia; 103,54g/dia; 199,96g/dia, respectivamente. O nitrogênio excretado na urina e nitrogênio excretado total foram $16,24 \%$ e $60,71 \%$, respectivamente. A concentração média de nitrogênio ureico no leite, na urina e no sangue foram de 3,95mg/dL; 4,32mg/dL e $23,73 \mathrm{mg} / \mathrm{dL}$, respectivamente. A excreção média de derivados de purina, alantoína, purinas absorvíveis, nitrogênio microbiano, proteína microbiana $\mathrm{e}$ relação proteína microbiana e nutrientes digetíveis totais foram de $321,68 \mathrm{mmol} / \mathrm{dia}$; 296,35 mmol/dia; 334,61 mmol/dia; 210,6g/dia; $1316,27 \mathrm{~g} / \mathrm{dia} ; 127,36 \mathrm{~g} / \mathrm{kg}$, respectivamente. A substituição parcial do farelo de soja por ureia convencional e/ou ureia encapsulada na alimentação de vacas lactantes proporcionou resultados semelhantes no balanço de compostos nitrogenados, nas concentrações de nitrogênio da urina e do leite e na síntese de proteína microbiana.

Palavras-chave: balanço de nitrogênio, produção microbiana, ureia encapsulada 


\section{INTRODUCTION}

According to Bach et al. (2005), N metabolism can be split into two separate events: the degradation of nitrogen compounds and the synthesis of microbial protein. Rumen microorganisms have the ability to transform dietary nitrogen into high quality protein. This nitrogen can come from both true protein of foods, as from some inorganic compounds (nonprotein nitrogen compounds), such as urea, biuret and uric acid.

The determination of nitrogen balance allows the quantification of retention or loss of protein by the animal, related to the consumption of a particular feed. The optimization of the balance between microbial protein synthesis and protein degradation in the rumen in lactating dairy cows has the potential to increase milk production and reduce nitrogen excretion into the environment (IMAIZUMI et al., 2010).

The use of forage by cattle is directly related to rumen microbial activity, especially on fiber compounds, which depend on the level of nitrogen compounds in the environment (COSTA et al., 2011).

Researchers have associated the supplementation of nitrogen compounds in the diet with the metabolism (HOJMAN, 2004), through analysis of urea nitrogen in blood and milk, in order to maximize the use of nitrogen in the diet of lactating cows. The concentration of milk urea nitrogen (MUN) is a useful tool to monitor the protein nutritional status and health of a cow herd, besides being beneficial to reduce losses and maximize the nitrogen utilization efficiency (ROY et al., 2011).

The present study aimed at evaluating nitrogen balance, levels of nitrogen in serum, urine and milk, and microbial protein synthesis, according to diets with partial replacement of soybean meal by conventional and/or coated urea in feeding dairy cows.

\section{MATERIAL AND METHODS}

The experiment was conducted at Paulistinha Farm, in the municipality of Macarani, Bahia State, and at the Universidade Estadual do Sudoeste da Bahia (UESB), campus of Itapetinga, Bahia. The study included eight crossbred cows (Holandês x Zebu) of the third or fourth lactation with previous production between 3,000 and $4,000 \mathrm{~kg}$ adjusted to 305 days. Animals had a body weight of $445 \mathrm{~kg} \pm 9 \mathrm{~kg}$, and about 60 days in milk at the beginning of the experimental period.

Cows were confined, randomly distributed, and assigned to a sequence of four experimental diets in a design distributed in two $4 \times 4$ Latin squares. $\mathrm{SM}=$ soybean meal (control); SRU $0=$ conventional urea (CU) 100\%; SRU 44 $=\mathrm{CU} 56 \% /$ SRU 44\%; SRU $88=\mathrm{CU}$ 12\%/ SRU 88\%. Experimental periods had 21 days, with the period between the $1^{\text {st }}$ and $14^{\text {th }}$ day for adaptation of animals to diets supplied, and the period between the $15^{\text {th }}$ and $21^{\text {st }}$ day for collecting samples, with a total duration of 84 days. Animals were confined in roofed, sand-floored individual pens with three square meters area, provided with feeders and drinkers

Diets were calculated to meet maintenance requirements, considering a production of $12 \mathrm{~kg}$ milk/day, $3.5 \%$ fat, according to the National Research Council (NRC, 2001).

Animals fed diets containing 70\% forage and 30\% concentrate (Table 1). The forage used was sugarcane (Saccharum). In order to compose the concentrate feeds were used: corn, wheat, soybean, urea and mineral mixture. Sources of urea used were 
conventional urea and slow release urea - Optigen ${ }^{\circledR} I I$ (Alltech Inc., Nicholasville, USA), and the control diet had soybean meal. The mixture of forage and concentrate was performed at the time of supply of feed.

Sugarcane (Saccharum officinarum) variety RB 72-454 was harvested daily and ground with leaves in forage machine at the time of supply. Weekly samples were taken for determination of DM and adjustment of forage: concentrate ratio of the diet. The average concentration of soluble sugars ( ${ }^{\circ}$ BRIX) of the material analyzed was $18.0^{\circ}$, analyzed by refractometer.

Table 1. Proportion of ingredients and chemical composition of experimental diets

\begin{tabular}{|c|c|c|c|c|}
\hline \multirow{2}{*}{ Ingredients \% DM } & \multicolumn{4}{|c|}{ Experimental diets } \\
\hline & FS & SRU 0 & SRU 44 & SRU 88 \\
\hline Sugarcane & 70.0 & 70.0 & 70.0 & 70.0 \\
\hline Ground corn grain & 6.8 & 20.7 & 20.6 & 20.6 \\
\hline Soybean meal & 22.0 & 6.0 & 5.9 & 5.9 \\
\hline Mineral mix & 0.7 & 0.7 & 0.7 & 0.7 \\
\hline Urea & 0 & 2.1 & 1.38 & 0.46 \\
\hline Slow release urea & 0 & 0 & 0.92 & 1.84 \\
\hline \multirow[t]{2}{*}{ Limestone } & 0.5 & 0.5 & 0.5 & 0.5 \\
\hline & \multicolumn{4}{|c|}{$\%$ Nutrient } \\
\hline $\mathrm{OM}$ & 99.8 & 99.8 & 99.8 & 99.8 \\
\hline $\mathrm{CP}$ & 15.8 & 17.5 & 16.5 & 15.6 \\
\hline TDN & 72.5 & 71.5 & 71.9 & 71.1 \\
\hline NDF & 48.9 & 52.0 & 50.2 & 49.3 \\
\hline $\mathrm{EE}$ & 2.8 & 2.7 & 3.1 & 2.8 \\
\hline NFC & 32.1 & 25.7 & 28.9 & 29.4 \\
\hline
\end{tabular}

Mineral mixture: Calcium - 165.00g/kg; Phosphorus - 78.00g/kg; Sulfur - 26.00g/kg; Magnesium $20.00 \mathrm{~g} / \mathrm{kg}$; Sodium - $114.00 \mathrm{~g} / \mathrm{kg}$; Cobalt - 90.00mg/kg; Copper - 1,238.00mg/kg; Chromium $20.00 \mathrm{mg} / \mathrm{kg}$; Iron - 2,000.00mg/kg; Iodine $-80.00 \mathrm{mg} / \mathrm{kg}$; Manganese $-2,057.00 \mathrm{mg} / \mathrm{kg}$; Selenium $27.50 \mathrm{mg} / \mathrm{kg}$; Zinc $-4,896.00 \mathrm{mg} / \mathrm{kg}$; Fluorine $-780.00 \mathrm{mg} / \mathrm{kg}$.

$\mathrm{CP}=$ crude protein; $\mathrm{TDN}=$ total digestible nutrient; $\mathrm{NDF}=$ neutral detergent fiber; $\mathrm{EE}=$ ether extract; $\mathrm{NFC}=$ non-fibrous carbohydrates; $\mathrm{SM}=$ soybean meal; $\mathrm{SRU}=$ slow release urea.

Diets were supplied in the morning at 7:00, and in the afternoon at 16:00, in sufficient amount to result in at least $10 \%$ of the supplied as daily surplus. Leftovers were collected and weighed daily, by the morning, before the first feeding, for adjusting of consumption. Daily consumption of natural material was determined by subtracting the total food supplied in two feedings, the weight of the surplus, from $15^{\text {th }}$ to $21^{\text {st }}$ day of each period. Cows were weighed at the beginning and end of each experimental period, to estimate the consumption of nutrients in percentage of body weight and to check the variation of body weight per treatment.
Daily samples were collected of each ingredient of diet and leftovers, per animal, and composite samples were formed on the basis of quantities of natural material. These samples were dried in a forced air oven for $72 \mathrm{~h}$, at $55^{\circ} \mathrm{C}$, and milled in a Thomas-Wiley mill with $1 \mathrm{~mm}$ sieve. A subsample was ovendried at $105^{\circ} \mathrm{C}$, for $24 \mathrm{~h}$, to determine the final dry matter. Afterwards, the intake of dry matter was calculated by multiplying the value of the diet dry matter by the daily intake of natural material.

Analyses of dry matter (DM), organic matter $(\mathrm{OM})$, total nitrogen, neutral detergent fiber (NDF), acid detergent fiber (ADF), ether extract (EE), mineral matter (MM) and neutral detergent 
insoluble nitrogen (NDIN) of food, leftovers and feces were performed according to the procedures described by Silva \& Queiroz (2002).

For the analysis of ether extract, were weighed $2.0 \mathrm{~g}$ of samples of sugarcane, leftovers, feces and concentrates, which were wrapped in tissue paper napkins $(14.0 \mathrm{~cm} \times 14.0 \mathrm{~cm})$, in the form of cartridges. The ends were clipped and samples were taken to a forced air oven at $55^{\circ} \mathrm{C}$ for $12 \mathrm{~h}$, kept in a desiccator until reaching room temperature and then weighed (SILVA \& QUEIROZ, 2002).

Each cartridge was placed in the soxhlet extractor fractionated connections and kept under heating for $5 \mathrm{~h}$ for fat extraction with petroleum ether, adding about $30 \mathrm{~mL}$ of ether per cartridge to flat-bottomed round flasks with a capacity of $500 \mathrm{ml}$. After extraction, flasks were taken again to a forced air oven at $55^{\circ} \mathrm{C}$ for $12 \mathrm{~h}$. The fat content was obtained from the difference between the weights of the flasks before and after extraction, and then adjusted to DM (SILVA \& QUEIROZ, 2002)

The percentage of total carbohydrates (TC) was obtained by the equation: 100 - (\% CP +\% EE +\% ash) and the percentage of NFC was calculated as $100-(\% \mathrm{NDF} p \mathrm{\%}+\% \mathrm{CP}+\% \mathrm{EE}+$ $\%$ ash) (SNIFFEN et al., 1992). For the calculation of TDN, we used the equation proposed by NRC (2001):

$$
\mathrm{TDN}=\mathrm{DCP}+2.25 \mathrm{x} \mathrm{DEE}++\mathrm{NDFcpD}+\mathrm{DNFC} .
$$

Where:

$\mathrm{DCP}=$ digestible crude protein;

$\mathrm{DEE}=$ digestible ether extract;

$\mathrm{NDF} c \mathrm{D}=$ neutral detergent fiber (corrected for ash and protein);

DNFC $=$ digestible non-fibrous carbohydrates.

Feces collection was performed during the second, fourth and sixth days of each collection period, there were intermittent collectionsfaeces from 7 hours, at intervals of 1 hour and 30 minutes, between the $14^{\text {th }}$ and $21^{\text {st }}$ experimental day. Feces of each cow were frozen throughout samplings and formed a composite sampled at the end of each period. The compounds per cow were dried, and NDF, ash and nitrogen were analyzed.

In order to estimate the apparent digestibility of nutrients, feces of animals were collected. For estimating fecal output it was used indigestible neutral detergent fiber (iNDF) as internal marker. Samples of supplied food (sugarcane and concentrate), leftovers and feces were incubated for 240 hours (CASALI et al.,
$2008)$, in duplicate $\left(20 \mathrm{mg} \mathrm{DM} / \mathrm{cm}^{2}\right)$, in non-woven fabric bags $\left(100 \mathrm{~g} / \mathrm{m}^{2}\right)$ in the rumen of a Holstein $x$ Zebu crossbred calf. Next, the remaining material was subjected to extraction with neutral detergent (MERTENS, 2002) for quantification of iNDF. Values of fecal output were obtained through the relationship between intake and fecal concentration of iNDF

Milk production was assessed from the $14^{\text {th }}$ to the $21^{\text {st }}$ day of each experimental period. Cows were milked twice daily at 6:00 and at 16:00h. Samples were composed of milk from morning and afternoon milkings, and the proportion was determined by the production in respective milkings. In each sample, we determined the levels of fat, protein and urea in milk. Of this composite sample, an aliquot of $10 \mathrm{~mL}$ was mixed with $5 \mathrm{~mL} 25 \%$ trichloroacetic acid, filtered through filter paper, and the supernatant stored at $-20^{\circ} \mathrm{C}$ for later analysis of urea and allantoin in the deproteinized milk (VALADARES et al., 1999). 
From the $15^{\text {th }}$ to $21^{\text {st }}$ days, spot urine collections were performed in spontaneous urination of animals, around 4 hours after the morning feeding supply, as described by Barbosa et al. (2006). Samples were filtered through cheesecloth, and a 10mL-aliquot was diluted with $40 \mathrm{ml} 0.036 \mathrm{~N}$ sulfuric acid (VALADARES et al. 1999), and subsequently intended for the quantification of urinary levels of urea nitrogen, creatinine, allantoin. Blood was collected from the jugular vein, on the day 21 , approximately 4 hours after the morning feeding supply, using $5 \mathrm{~mL}$ Vacutainer tubes. Blood samples were then taken to the laboratory, centrifuged at 3500rpm for 10 minutes, and the serum was stored frozen $\left(-20^{\circ} \mathrm{C}\right)$ in $5 \mathrm{~mL}$ microcentrifuge tubes until analysis. Concentrations of creatinine and uric acid in urine and urea in urine and serum were estimated using commercial kits. The conversion of urea into urea nitrogen was performed by multiplying the values obtained by the factor 0.4667 . The urinary allantoin level was obtained by colorimetric methods, as specified by Chen \& Gomes (1992), and the total nitrogen content, estimated by the Kjeldahl method (SILVA \& QUEIROZ, 2002). Dividing the constant value of 24.54 (PEREIRA, 2003), for excretion average daily creatinine in $\mathrm{mg} / \mathrm{kg} \mathrm{BW}$ (body weight), the creatinine concentration $(\mathrm{mg} / \mathrm{L})$ in the urine sample spot, will be estimated volume daily urine. This volume will be used to estimate the excretions daily allantoin, urea and nitrogen of each animal.

Nitrogen balance ( $\mathrm{N}$ retained, g/day) was calculated as:

$$
\mathrm{N} \text { retained }(\mathrm{g})=\{\mathrm{N} \text { consumed }(\mathrm{g})-\mathrm{N} \text { feces }(\mathrm{g})-\mathrm{N} \text { urine }(\mathrm{g})\}
$$

Where: $\mathrm{N}$ retained $=$ nitrogen retained in the organism; $\mathrm{N}$ consumed $=$ nitrogen consumed by the animal; $\mathrm{N}$ feces = nitrogen excreted in the feces and $\mathrm{N}$ urine $=$ nitrogen excreted in the urine.

The excretion of total purine derivatives (TP) was estimated by the sum of allantoin and uric acid excreted in the urine, and the amount of microbial purines absorbed (mmol/day) by excretion of total purine derivatives (mmol/day) through the equation proposed by Verbic et al. (1990):

$$
\mathrm{PA}=\left\{\frac{\mathrm{TP}-0.385 \times \mathrm{PC}^{0.75}}{0.85}\right\}
$$

Where: PA $=$ purine absorbed $(\mathrm{mmol} /$ day) and $\mathrm{TP}=$ total purine $(\mathrm{mmol} /$ day $) ; 0.85=$ recovery of purines absorbed as purine derivatives in the urine, and $0.385=$ endogenous excretion of purine derivatives in the urine (mmol), per metabolic weight $\left(\mathrm{PC}^{0.75}\right)$.

For estimating microbial protein synthesis, purine bases were used (mmol/day) as a microbial marker, whose quantification used the equation proposed by Chen \& Gomes (1992):

$$
\mathrm{NM}(\mathrm{g} / \text { day })=\left\{\frac{70 \times \mathrm{PA}}{0.83 \times 0.116 \times 1,000}\right\}
$$

By assuming the value 70 for the nitrogen content in purines $(\mathrm{mg} / \mathrm{mmol})$; 0.83 for intestinal digestibility of microbial purines and 0.116 for the $\mathrm{N}_{\text {PURINE }}: \mathrm{N}_{\text {TOTAL }}$ ratio in bacteria.

The results were statistically interpreted and subjected to contrast analysis at 5\% probability to determine the behavior of responses obtained, whether linear or quadratic. All statistical procedures were run with the software SAS (STATISTICAL ANALYSIS SYSTEM, 2002). 


\section{RESULTS AND DISCUSSION}

Table 2 showed that replacing soybean meal by conventional and coated urea, at $2.1 \%$ dry matter of the concentrate caused no significant effect. As for variables of nitrogen intake, retained nitrogen balance, excretion of nitrogen in milk, urine and feces, and total $\mathrm{N}$ excreted, mean values were 340.27 ; 136.73; 43.25; 53.17; 103.54; $199.96 \mathrm{~g} /$ day, respectively.

Table 2. Mean values of total nitrogen intake (TNI), nitrogen excretion in milk (NEM), urine (NEU) and feces (NEF), nitrogen balance (NB) and total nitrogen excreted (TNE), observed in dairy cows according to experimental diets

\begin{tabular}{lcccccc}
\hline Experimental diets & $\begin{array}{c}\text { TNI } \\
(\mathrm{g} / \text { day })\end{array}$ & $\begin{array}{c}\text { NEM } \\
(\mathrm{g} / \text { day })\end{array}$ & $\begin{array}{c}\text { NEU } \\
(\mathrm{g} / \text { day })\end{array}$ & $\begin{array}{c}\text { NEF } \\
(\mathrm{g} / \text { day })\end{array}$ & $\begin{array}{c}\text { NB } \\
(\mathrm{g} / \text { day })\end{array}$ & $\begin{array}{c}\text { TNE } \\
(\mathrm{g} / \text { day })\end{array}$ \\
\hline SM & 342.21 & 46.65 & 51.20 & 107.62 & 136.73 & 205.47 \\
SRU 0 & 346.08 & 38.54 & 60.35 & 92.64 & 154.55 & 191.54 \\
SRU 44 & 313.71 & 43.50 & 50.94 & 109.67 & 109.6 & 204.11 \\
SRU 88 & 359.09 & 44.31 & 50.18 & 104.25 & 160.34 & 198.75 \\
\hline Mean & 340.27 & 43.25 & 53.17 & 103.54 & 140.3 & 199.96 \\
SEM & 16.3 & 1.90 & 3.82 & 5.54 & 12.5 & 7.14 \\
\hline L* & 0.7392 & 0.2509 & 0.2295 & 0.3368 & 0.8172 & 0.6999 \\
$Q^{*}$ & 0.2631 & 0.6242 & 0.5428 & 0.2824 & 0.0512 & 0.5784 \\
\hline 1 vs. $(2+3+4)$ & 0.9294 & 0.2714 & 0.7054 & 0.5925 & 0.8359 & 0.6131 \\
2 vs. $3+4)$ & 0.7539 & 0.2211 & 0.1936 & 0.1904 & 0.4250 & 0.5213 \\
1 vs. 2 & 0.9134 & 0.1137 & 0.2886 & 0.2339 & 0.5286 & 0.4349 \\
1 vs. 3 & 0.4269 & 0.5286 & 0.9756 & 0.8690 & 0.3397 & 0.9388 \\
1 vs. 4 & 0.6364 & 0.6393 & 0.9048 & 0.7857 & 0.4050 & 0.7050 \\
2 vs. 3 & 0.3676 & 0.3242 & 0.2756 & 0.1778 & 0.1197 & 0.4806 \\
2 vs. 4 & 0.7155 & 0.2532 & 0.2401 & 0.3537 & 0.8369 & 0.6849 \\
3 vs. 4 & 0.2102 & 0.8703 & 0.9290 & 0.6627 & 0.0810 & 0.7625 \\
\hline
\end{tabular}

$\mathrm{SM}=$ soybean meal; SRU $0=$ conventional urea $(\mathrm{CU}) 100 \%$ / slow release urea (SRU) 0\%; SRU $44=$ CU 56\% / SRU 44\%; SRU 88 = CU 12\% / SRU 88\%; L* =linear Q*= quadratic; SEM: standard error of the mean; Contrasts: 1 - SM; 2 - SRU 0; 3 - SRU 44; 4 - SRU 88. NI = nitrogen intake. NE = nitrogen excreted. $\mathrm{TN}=$ total nitrogen. $*=$ Significant at $5 \%$ probability.

The nitrogen consumption in experimental diets was lower than found by Vasconcelos et al. (2010), when used soybean and urea to lactating cows, $533.48 \mathrm{~g} /$ day. In relation to retained nitrogen balance, the value was higher than registered by Vasconcelos et al. (2010) (92.19g/day) who observed greater excretion in feces, urine and milk, with mean values of 150.38 ; $147.55 ; 143.38 \mathrm{~g} /$ day. The $\mathrm{N}$ intake is provided by conventional and slow release urea which, in the form of ammonia $\left(\mathrm{N}-\mathrm{NH}_{3}\right)$, in the rumen passes by diffusion through the rumen epithelium and reaches the bloodstream, where a portion is recycled by saliva and another part is transformed in the liver into urea (AZEVEDO et al., 2010). According to Cavalcante et al. (2006), the increased use of nitrogen compounds occurs when using diets with lower protein levels, because the excessive increase of dietary $\mathrm{CP}$ may result in the excessive release of urea via the urine, constituting waste of protein. 
The positive nitrogen balance indicates retention of protein in the organism, providing conditions that prevent performance loss, which probably means that the requirements of protein in the diets were met. According to Hoffman et al. (2001), there is a linear relationship between nitrogen intake and nitrogen excretion in feces and urine.

In the present study, due to the degradation rate of nitrogen compounds, the speed of use of $\mathrm{N}$ by rumen microorganisms for growth may have caused an imbalance between $\mathrm{N}$ and energy in the rumen, a decrease in use efficiency of nitrogen compounds, and consequently, a higher synthesis of urea by the liver, with subsequent urinary excretion. Associating this variable to $\mathrm{N}$ intake, there was an increased excretion of $\mathrm{N}$, which is not desirable in production systems (PEREIRA et al., 2007).

The average percentage of $\mathrm{N}$ excretion in milk was $12.52 \%$. Contrast analyses revealed that cows of the treatment with $100 \%$ conventional urea excreted less $\mathrm{N}$ in milk, with difference in relation to other experimental diets with coated urea (Table 3).

Table 3. Mean percentage of nitrogen excretion in milk (NEM), urine (NEU) and feces (NEF), nitrogen retained (NR) and total nitrogen excreted (TNE), observed in dairy cows according to experimental diets

\begin{tabular}{|c|c|c|c|c|c|}
\hline Experimental diets & E.N.L. $(\%)$ & E.N.U. (\%) & E.N.F. (\%) & N.R. (\%) & N.T.E. $(\%)$ \\
\hline SM & 13.70 & 14.69 & 31.89 & 39.70 & 60.29 \\
\hline SRU 0 & 10.52 & 19.06 & 27.75 & 42.65 & 57.34 \\
\hline SRU 44 & 14.16 & 16.51 & 36.25 & 33.06 & 66.93 \\
\hline SRU 88 & 13.31 & 14.72 & 30.26 & 41.70 & 58.34 \\
\hline Mean & 12.92 & 16.24 & 31.54 & 39.28 & 60.71 \\
\hline SEM & 0.67 & 1.18 & 1.83 & 2.08 & 2.08 \\
\hline $\mathrm{L}^{*}$ & 0.0794 & 0.0622 & 0.2837 & 0.7605 & 0.7605 \\
\hline $\mathrm{Q}^{*}$ & 0.0968 & 0.8344 & $0.0028 *$ & $0.0045^{*}$ & 0.0045 \\
\hline 1 vs. $(2+3+4)$ & 0.4068 & 0.3916 & 0.8569 & 0.8872 & 0.8872 \\
\hline 2 vs. $(3+4)$ & $0.0237 *$ & 0.1868 & 0.0567 & 0.2201 & 0.2201 \\
\hline 1 vs. 2 & $0.0482 *$ & 0.1486 & 0.2044 & 0.5476 & 0.5479 \\
\hline 1 vs. 3 & 0.7633 & 0.5367 & 0.1829 & 0.1820 & 0.1820 \\
\hline 1 vs. 4 & 0.7930 & 0.9911 & 0.6123 & 0.6830 & 0.6830 \\
\hline 2 vs. 3 & $0.0260 *$ & 0.3909 & $0.0132 *$ & 0.0588 & 0.0588 \\
\hline 2 vs. 4 & 0.0802 & 0.1515 & 0.4366 & 0.8458 & 0.8458 \\
\hline 3 vs. 4 & 0.5744 & 0.5440 & 0.0716 & 0.0864 & 0.0864 \\
\hline
\end{tabular}

$\mathrm{SM}=$ soybean meal; SRU $0=$ conventional urea $(\mathrm{CU}) 100 \% /$ slow release urea (SRU) $0 \%$; SRU $44=$ CU 56\% / SRU 44\%; SRU $88=$ CU 12\% / SRU 88\%; L* =linear $Q^{*}=$ quadratic; SEM: standard error of the mean; Contrasts: 1 - SM; 2 - SRU 0; 3 - SRU 44; 4 - SRU 88. NE = nitrogen excreted. $\mathrm{TN}=$ total nitrogen. ${ }^{*}=$ Significant at $5 \%$ probability.

When replacing soybean meal by nitrogen sources used in supplying the diet, we observed similar percentages of nitrogen excreted in urine, and of total nitrogen excreted between experimental diets, with mean values of 16.24 and $60.71(\%)$, respectively (Table 3$)$.
No effect was detected on excretion of total nitrogen in experimental diets. The greater excretion of $\mathrm{N}$ in the diet with sugarcane and different sources of $\mathrm{N}$ was in feces, with average of $31.54 \%$. There was a difference $(\mathrm{P}<0.05)$ between experimental diets with the use 
of $100 \%$ conventional urea and in the diet added with $44 \%$ coated urea, and the use of $44 \%$ slow release urea promoted the greatest excretion of $\mathrm{N}$ in feces, with $36.25 \%$.

A positive association was observed in the experimental diet with $100 \%$ conventional urea, with reduced percentage of excretion of $\mathrm{N}$ in feces and milk, and increased percentage of nitrogen retention.

The average percentage of $\mathrm{N}$ retained was $39.28 \%$, with the highest percentage obtained in the experimental diet using 100\% conventional urea. The summation of $\mathrm{N}$ excretion found in all treatments was higher than the retained balance. Therefore it is observed in treatments that achieved a greater balance of retained $\mathrm{N}$ as for aspects of lower fecal excretion.

The excess of rumen degradable protein leads to excess of $\mathrm{NH} 3$ that can affect the amount of energy available to the animal. In kidneys, muscle and brain, glutamic acid reacts with $\mathrm{NH} 3$ to form glutamine. The immediate source of glutamic acid is alpha-ketoglutarate, an intermediate in the citric acid cycle, which is essential for the formation of energy in the animal.

Nevertheless, recycling of urea in the rumen (HALL et al., 2008) may have been a factor compensator of the faster release of urea, which may explain the lack of effect on animal performance.

The replacement of soybean meal by conventional urea and of coated urea by soybean meal, used in providing the sugarcane based-diet, presented similar values among diets in the concentration of urea in milk and urea nitrogen in milk, and the results of the averages were $29.94 \mathrm{mg} / \mathrm{dL}$ and $13.95 \mathrm{mg} / \mathrm{dL}$, respectively (Table 4).

Table 4. Mean values relative to milk urea concentration, milk urea nitrogen, serum urea, serum urea nitrogen, urine urea, urine urea nitrogen and creatinine observed in dairy cows, according to experimental diets

\begin{tabular}{|c|c|c|c|c|c|c|c|}
\hline Experimental diets & $\begin{array}{l}\text { Urea/ } \\
\text { Milk } \\
(\mathrm{mg} / \mathrm{dL})\end{array}$ & $\begin{array}{c}\text { UN/ } \\
\text { Milk } \\
(\mathrm{mg} / \mathrm{dL})\end{array}$ & $\begin{array}{l}\text { Urea/ } \\
\text { urine } \\
(\mathrm{mg} / \mathrm{dL})\end{array}$ & $\begin{array}{l}\text { UN / urine } \\
\text { (mg/dL) }\end{array}$ & $\begin{array}{c}\text { Serum } \\
\text { urea } \\
(\mathrm{MG} / \mathrm{dL})\end{array}$ & $\begin{array}{c}\mathrm{UN} / \\
\text { blood } \\
(\mathrm{mg} / \mathrm{dL})\end{array}$ & $\begin{array}{c}\text { Creatinine } \\
(\mathrm{mg} / \mathrm{dL})\end{array}$ \\
\hline FS & 27.47 & 12.8 & 8.02 & 3.73 & 54.42 & 25.57 & 1.3563 \\
\hline SRU 0 & 28.18 & 13.13 & 10.65 & 4.96 & 54.02 & 25.39 & 1.4113 \\
\hline SRU 44 & 31.88 & 14.85 & 10.57 & 4.92 & 50.58 & 23.77 & 1.1562 \\
\hline SRU 88 & 32.23 & 15.02 & 7.88 & 3.67 & 42.95 & 20.18 & 1.2875 \\
\hline Mean & 29.94 & 13.95 & 9.28 & 4.32 & 50.49 & 23.73 & 1.3028 \\
\hline SEM & 1.56 & 0.73 & 0.6 & 0.28 & 2 & 0.94 & 0.05 \\
\hline $\mathrm{L}^{*}$ & 0.1952 & 0.1952 & 0.109 & 0.1089 & $0.0241 *$ & $0.0241 *$ & 0.3821 \\
\hline $\mathrm{Q}^{*}$ & 0.3609 & 0.3609 & 0.3714 & 0.3713 & 0.5857 & 0.5857 & 0.1257 \\
\hline 1vs. $(2+3+4)$ & 0.3119 & 0.3117 & 0.1748 & 0.1748 & 0.1589 & 0.1589 & 0.5890 \\
\hline 2 vs. $(3+4)$ & 0.2635 & 0.2635 & 0.2769 & 0.2769 & 0.0709 & 0.0709 & 0.1849 \\
\hline 1 vs. 2 & 0.8568 & 0.8564 & 0.0871 & 0.0871 & 0.928 & 0.928 & 0.7328 \\
\hline 1 vs. 3 & 0.2702 & 0.2701 & 0.0958 & 0.0958 & 0.3908 & 0.3908 & 0.2235 \\
\hline 1 vs. 4 & 0.2349 & 0.2347 & 0.9271 & 0.927 & $0.017 *$ & $0.017 *$ & 0.6699 \\
\hline 2 vs. 3 & 0.3531 & 0.3531 & 0.9601 & 0.9603 & 0.4412 & 0.4412 & 0.1253 \\
\hline 2 vs. 4 & 0.31 & 0.31 & 0.0728 & 0.0728 & $0.0206^{*}$ & $0.0206 *$ & 0.4455 \\
\hline 3 vs. 4 & 0.9287 & 0.9286 & 0.0803 & 0.0803 & 0.0971 & 0.0971 & 0.4188 \\
\hline
\end{tabular}


Our results were lower than found by Silveira et al. (2012) who analyzed the replacement of soybean meal by Optigen II in lactating cows, and observed an increase in the content of NUL, from 16.3 to $17.0 \mathrm{mg} / \mathrm{dL}$, respectively. Therefore, the diet of sugarcane promoted satisfactory values of urea nitrogen in milk, because the presence of fermentable carbohydrates combined with nitrogen compounds indicate a better synchrony in the rumen.

Inostroza et al. (2010) verified that the partial replacement of soybean meal by OptigenII increased the content of NUL. This was not registered by Santos et al. (2011), when the soybean meal was replaced by OptigenII plus citrus pulp, neither by Souza et al. (2010), when the soybean meal was replaced by OptigenII plus soybean hulls.

The average urinary excretion of urea obtained and urea nitrogen were 9.28 and $4.32 \mathrm{mg} / \mathrm{dL}$, with no significant difference between diets. This possibly indicated a balance in diet use.

The results referring to concentration of serum urea and of serum urea nitrogen between treatments were 50.49 and $23.73 \mathrm{mg} / \mathrm{dL}$, respectively. It was observed a linear decreasing trend according to the increase of the proportion of slow-release urea. Although the levels of serum urea and of urea nitrogen in blood were high, the gradual increase of coated urea in diets appeared to improve the efficiency of utilization of ammonia in the rumen, resulting in a decrease of the increased level of blood urea nitrogen. In this study, heifers that consumed supplements with low PNDR showed average plasma concentration of urea-N of $19.38 \mathrm{mg} / \mathrm{dL}$ (Table 5) and probably would have reproductive performance impaired with continuous administration of this type of diet.

Table 5. Mean values of purine derivatives excretion, nitrogen synthesis, microbial protein and microbial efficiency in dairy cows according to experimental diets

\begin{tabular}{lcccccc}
\hline $\begin{array}{l}\text { Experimental } \\
\text { diets }\end{array}$ & $\begin{array}{c}\text { Purine derivatives } \\
(\mathrm{mmol} / \text { day })\end{array}$ & $\begin{array}{c}\text { Allantoir } \\
(\mathrm{mmol} / \mathrm{da}\end{array}$ & $\begin{array}{c}\text { Absorbed purines } \\
(\mathrm{mmol} / \mathrm{day})\end{array}$ & $\begin{array}{c}\mathrm{N} / \mathrm{micro} \\
(\mathrm{g} / \text { day })\end{array}$ & $\begin{array}{c}\mathrm{P} / \mathrm{micro} \\
(\mathrm{g} / \mathrm{day})\end{array}$ & $\begin{array}{c}\mathrm{P} / \mathrm{micro} / \\
\mathrm{TDN} \\
(\mathrm{g} / \mathrm{kg})\end{array}$ \\
\hline SM & 335.17 & 309.53 & 349.6 & 220.03 & 1375.22 & 127.19 \\
SRU 0 & 317.79 & 291.27 & 330.89 & 208.25 & 1307.59 & 133.74 \\
SRU 44 & 337.52 & 311.61 & 353.89 & 222.28 & 1389.24 & 128.64 \\
SRU 88 & 296.27 & 273.02 & 304.81 & 191.85 & 1199.03 & 124.17 \\
\hline Mean & 321.68 & 296.35 & 334.61 & 210.6 & 1316.27 & 127.36 \\
EPM & 27.1 & 25.70 & 31.7 & 20.0 & 125.0 & 11.9 \\
\hline $\mathrm{L}^{*}$ & 0.7481 & 0.7306 & 0.7577 & 0.7577 & 0.7577 & 0.9002 \\
$\mathrm{Q}^{*}$ & 0.5601 & 0.5825 & 0.5570 & 0.5570 & 0.5570 & 0.8073 \\
\hline 1 vs. $(2+3+4)$ & 0.7332 & 0.7283 & 0.7472 & 0.7472 & 0.7472 & 0.9492 \\
2 vs. $(3+4)$ & 0.9872 & 0.9844 & 0.9770 & 0.9770 & 0.9770 & 0.8008 \\
1 vs. 2 & 0.7877 & 0.7680 & 0.8051 & 0.8051 & 0.8051 & 0.8431 \\
1 vs. 3 & 0.9709 & 0.9732 & 0.9625 & 0.9625 & 0.9625 & 0.9634 \\
1 vs. 4 & 0.5484 & 0.5568 & 0.5565 & 0.5565 & 0.5565 & 0.9236 \\
2 vs. 3 & 0.7599 & 0.7426 & 0.7690 & 0.7690 & 0.7690 & 0.8774 \\
2 vs. 4 & 0.7390 & 0.7681 & 0.7313 & 0.7313 & 0.7313 & 0.7724 \\
3 vs. 4 & 0.5247 & 0.5348 & 0.5259 & 0.5259 & 0.5259 & 0.8873 \\
\hline
\end{tabular}

$\mathrm{SM}=$ soybean meal; SRU $0=$ conventional urea $(\mathrm{CU}) 100 \%$ / slow release urea $(\mathrm{SRU}) 0 \%$; SRU $44=$ CU 56\% / SRU 44\%; SRU 88 = CU 12\% / SRU 88\%; L* =linear Q*= quadratic; SEM: standard error of the mean; Contrasts: 1 - SM; 2 - SRU 0; 3 - SRU 44; 4 - SRU 88. N/micro = microbial nitrogen. $\mathrm{P} /$ micro $=$ microbial protein. $\mathrm{TDN}=$ total digestible nutrients.

*Significant at $5 \%$ de probability. 
Creatinine, from the reaction of creatine to form muscle phosphocreatine, is indicative of kidney function and is only filtered and not reabsorbed by the kidneys. Creatinine is not associated with animal feeding, unlike urea as described above. The measurements of serum creatinine and urea, as indicated in the control of renal function, revealed that the sugarcane plus the replacement of conventional urea and coated urea administered for 84 days was not capable of causing renal disorders.

The results for variables in the excretion of purine derivatives, allantoin, absorbable purines, microbial nitrogen, microbial protein, microbial protein: total digestible nutrients ratio were similar between diets, averaging $321.68 \mathrm{mmol} /$ day; $296.35 \mathrm{mmol} / \mathrm{day} ; \quad 334.61 \mathrm{mmol} /$ day, $210.6 \mathrm{~g} /$ day; $\quad 1316.27 \mathrm{~g} /$ day and $127.36 \mathrm{~g} / \mathrm{kg}$, respectively, are shown in Table 5. Under the conditions of the present study, the partial replacement of soybean meal by conventional and coated urea had no influence on the capacity for microbial protein production, which is because the sugarcane contains a good amount of highly fermentable carbohydrates, allowing bacteria to use the additional nitrogen to turn it into microbial protein.consequently, the results of the present study suggest that thesource of urea or coated urea at the supplemented level has no effect on the ruminal fermentation.

The excretion of purine derivatives were lower than found by Vasconcelos et al. (2010) in Holstein cows supplemented with soybean meal, with average values of purine derivatives of 468.30mmol/day; and Pina et al. (2006), of $397.38 \mathrm{mmol} /$ day, with supply of different protein sources.

These results indicate that in cattle the level of allantoin is not constant throughout all physiologic and dietary treatments. Increasing levels of slow release urea in the diet with sugarcane did not alter the excretion of allantoin. Allantoin represented $92.1 \%$ of total purine derivatives excreted.

Chizzotti et al. (2007) and Braga et al. (2012), that is, $87.80 \%$; $86.60 \%$; $86.10 \%$; $90.46 \%$ and $89.69 \%$ respectively. These values suggest that the excretion of allantoin can be a good variable to represent the excretion of purine derivatives, in order to estimate the microbial protein production.

Chizzotti et al. (2007) observed variation in excretions of allantoin in dairy cows of high, medium and low milk production, with values of 323.70 ; $268.48 ; 160.18 \mathrm{mmol} /$ day, respectively. In their study, the authors found a lower excretion of allantoin in cows with low milk production.

The results of absorbed purines are close to the category of cows with average milk production observed by Orellana Boero et al. (2001), in an experiment with cows of high, medium and low production, whose values of absorbed purines were $395.41 ; 316.84$ and $169.08 \mathrm{mmol} /$ day, respectively. Gonzalez-Ronquillo et al. (2003) registered values of $433.33 ; 338.31$ and $153.39 \mathrm{mmol} /$ day, respectively.

The efficiency of microbial protein synthesis was not affected by the inclusion of slow-release urea in the diet. The average value was $127.36 \mathrm{~g}$ $\mathrm{CPmic} / \mathrm{kg}$ of TDN consumed, close to the value suggested by the NRC (2001), $130 \mathrm{gCPmic} / \mathrm{kg}$ of TDN. This lack of variation in microbial protein synthesis may be related to the protein-energy balance between diets. The value found here was higher than found by Morais (2000), 104g MCP/kg TDN, working with Holstein $\times$ Zebu cows, fed supplements with increasing levels of urea $(0 ; 1.2 ; 2.4 ; 3 ; 6 \%$ based on natural material). 
Pina et al. (2010), compiling several studies using animals for the production of meat and milk subjected to different feeding conditions, recommended a microbial efficiency of $120 \mathrm{~g} / \mathrm{kg}$ TDN as reference to tropical conditions. The highest microbial production is consistent with the highest consumption, which provided greater amount of fermentable substrates and the increased the rate of passage by increasing the drag of rumen microorganisms. At higher passage rates, the average age of microorganisms is reduced (Van SOEST, 1994), selecting organisms with shorter generation time and lower use of substrates for microbial maintenance and decreasing predation and nutrient recycling, which increases the microbial efficiency.

In a review, Cherdthong et al. (2010) concluded that the slow-release urea was more efficient in rumen fermentation, microbial protein synthesis and milk production, at the expense of conventional urea in ruminant feed. In our study, the use of coated urea did not modify the microbial production and efficiency.

and therefore one of the hypotheses that could interfere with microbial growth may be related to the forage: concentrate ratio.

The partial replacement of soybean meal by conventional urea and / or urea encapsulated in feeding lactating cows yielded similar results in nitrogenous compounds, the concentrations of nitrogen from urine and milk and microbial protein synthesis.

\section{REFERENCES}

AZEVEDO, E.B.; OSPINA-PATINO, H.; SILVEIRA, A.L.F.; LÓPEZ, J.; NÕRNBERG, J.L.; BRÜNING, G. Nitrogen supplement with common or coated urea on ruminal parameters of steers fed with low quality hay. Ciência Rural, v.40, n.3, p.622- 627, 2010.

BACH, A.; CALSAMIGLIA, S.; STERN, M.D. Nitrogen metabolism in the rumen. Journal of Dairy Science, v.88, p 9-20, 2005.

BARBOSA, A.M.; VALADARES, R.F.D.; VALADARES FILHO, S.C. VÉRAS, R.M.L.; LEÃO,M.I.; DETMANN, E.; PAULINO,M.F.; MARCONDES, M.I.; SOUZA, M.A. Effect of urinary collection days, concentrate levels and protein sources on creatinine, urea and purine derivatives excretions and microbial protein synthesis in Nellore cattle.

Revista Brasileira de Zootecnia, v.35, n.3, p.870-877, 2006.

BRAGA, J.M.S.; VALADARES, R.F.D.; PELLIZZONI, S.G. Estimation of endogenous contribution and urinary excretion of purine derivatives from the total digestible nutrient intake in Nellore heifers Revista Brasileira de Zootecnia, v.41, n.8, p.1899-1906, 2012

CASALI, A.O.; DETMANN, E.; VALADARES FILHO, S.C.; CARLOS, J.P.; HENRIQUES, L.T.; FREITAS, S.G.; PAULINO, M.F. Influence of incubation time and particles size on indigestible compounds contents in cattle feeds and feces obtained by in situ procedures. Revista Brasileira de Zootecnia, v.37, n.2, p.335-342, 2008. 
CAVALCANTE, M.A.B.; PEREIRA, O.G.; VALADADARES FILHO, S.C.; RIBEIRO, K.G., PACHECO,L.B.B., ARAÚJO, D.; LEMOS, V.M.C. Crude protein levels on beef cattle diets: ruminal metabolism, nitrogen balance, and microbial protein synthesis. Revista Brasileira de Zootecnia, v.35, n.1, p.203-210, 2006.

CHEN, X.B.; GOMES, M.J.

Estimation of microbial protein supply to sheep and cattle based on urinary excretion of purine derivatives- an overview of technical details. International feed research unit. Aberdeen: Rowett Research Institute, 1992. 21p.

CHERDTHONG, A; WANAPAT, $M$. Development of urea products as rumen slow- release feed for ruminant production: a review. Australian Journal of Basic and Applied Sciences, v.4, p.2232-2241, 2010.

CHIZZOTTI, M.L.; VALADARES FILHO, S.C.; VALADARES, R.F.D.; CHIZZOTTI, F.H.M.; MARCONDES, M.I.; FONSECA, M.A. Intake, digestibility and nitrogen metabolism in Holstein cows with different milk production levels. Revista Brasileira de Zootecnia, v.36, n.1, p.138-146, 2007.

COSTA, V.A.C.; DETMANN, E.; PAULINO, M.F. Total and partial digestibility and nitrogen balance in grazing cattle supplemented with nonprotein and, or true protein nitrogen during the rainy season. Revista Brasileira de Zootecnia, v.40, n.12, p.2815-2826, 2011.
GONZALEZ-RONQUILLO, M.; BALCELLS, J.; GUADA, J.A.; VICENTE, F. Purine derivative excretion in dairy cows: Endogenous excretion and the effect of exogenous nucleic acid supply. Journal of Dairy Science, v.86, n.4, p.1282-1291, 2003.

HALL, M.B.; HUNTINGTON, G.B. Nutrient synchrony: Sound in theory, elusive in practice. Journal Animal Science, v.86, p.287-292, 2008.

HOFFMAN, P.C.; ESSER, N.M.; BAUMAN, L.M.; DENZINE, S.L.; ENGSTROM, M.; CHESTER-JONES, H. Short communication: effect of dietary protein on growth and nitrogen balance of Holstein heifers. Journal of Dairy

Science, v.84, p.843-847, 2001.

HOJMAN, D. Relationships between milk urea and production, nutrition and fertility traits in Israeli Dairy herds.

Journal of Dairy Science, v.87, p.1001$11,2004$.

IMAIZUMI, H.; SANTOS, F.A.P.; BITTAR, C.M.M. Diet crude protein content and sources for lactating dairy cattle Science Agricola, v.67, n.1, p.1622, 2010.

INOSTROZA, J.F.; SHAVER, R.D.; CABRERA, V.E., TRICARICO, J.M. Effect of diets containing a controlledrelease urea product on milk yield, milk composition, and milk component yields in commercial Wisconsin dairy herds and economic implications. The Professional Animal Scientist, v.26, p.175-180, 2010.

MERTENS, D.R. Gravimetric determination of amylase-treated neutral detergent fiber in feeds with refluxing in beakers or crucibles: collaborative study. Journal of AOAC International, v.85, p.1217-1240, 2002. 
MORAIS, M.G.; RANGEL, J.M.; MADUREIRA, J.S.; SILVEIRA, A.C. Seasonal changes of clinical biochemistry of graded Nelore cows on continuous grazing of Brachiaria decumbens. Arquivo Brasileiro de Medicina Veterinaria e Zootecnia., v.52, n.2, p.98-104, 2000.

\section{NATIONAL RESEARCH COUNCIL -} NRC. Nutrient requirements of dairy cattle. 7.ed.rev. Washington, D.C.: National Academic Press, 2001. 381p.

ORELLANA BOERO, P.; BALCELLS, J.; MARTIIN-ORÚE, S.M., LINAG, J.B., GUADA, J.A. Excretion of purine derivates in cows: endogenous contribution and recovery of exogenous purine bases. Livestock Production Science, v.68, p.243-250, 2001.

PEREIRA, M.L.A. Proteína na dieta de vacas nos terços inicial e médio da lactação. 2003. 105p. Tese (Doutorado em Zootecnia) - Universidade Federal de Viçosa, Viçosa.

PEREIRA, K.P.; VÉRAS,A.S.C.; FERREIRA, M.A. Nitrogen balance and endogenous losses in cattle and buffaloes fed with increasing levels of concentrate. Acta Scientiarum Animal Science, v.29, n.4, p.433-440, 2007.

PINA, D.S.; VALADARES FILHO, S.C.; VALADARES, R.F.D.; DETMANN, E.; CAMPOS, J.M.S.; FONSECA, M.A.; TEIXEIRA, R.M.A.; OLIVEIRA, A.S.O. Estimation of microbial protein synthesis and urea nitrogen metabolism in lactating dairy cows fed diets supplemented with different protein sources. Revista Brasileira de Zootecnia, v.35, p.15511559, 2006.
PINA, D.S.; VALADARES FILHO, S.C.; AZEVEDO, J.A.G., BARBOSA, A.M.,VALADARES, R.F.D., DETMANN, E. Levels of inclusion and exposure time of sugar cane to calcium oxide on digestive parameters and performance of Nellore heifers. Revista Brasileira de Zootecnia, v.39, n.7, p.1579-1586, 2010.

ROY, B.; BRAHMA, B.; GHOSH, S.; ANKAJ, P.K.; MANDAL, G. Evaluation of milk urea concentration as useful indicator for dairy herd management: a review. Asian Journal of Animal and Veterinary Advances, v.6, p.1-19, 2011.

SANTOS, J.F.; DIAS JUNIOR, G.S.; BITENCOURT, L.L.; LOPES N.M.; SIÉCOLA JUNIOR, S.; SILVA, J.R.M.; PEREIRA, R.A.N.; PEREIRA, M.N. Response of lactating cows to the partial replacement of soybean meal by encapsulated urea. Arquivo Brasileiro de Medicina Veterinária e Zootecnia, v.63, p.423-432, 2011.

\section{SILVA, D.J.; QUEIROZ, A.C. Análise} de alimentos: métodos químicos e biológicos. Viçosa: Universidade Federal de Viçosa, 235p. 2002.

SILVEIRA, V.A.; LOPES, N.M.; OLIVEIRA, R.C. Partial replacement of soybean meal by slow release urea in commercial dairy herds. Revista Brasileira de Saúde Produção Animal [online], v.13, n.2, p.383-395, 2012.

SNIFFEN, C.J.; O'CONNOR, J.D.; Van SOEST, P.J.; FOX, D.J.; RUSSEL, J.B. A net carbohydrate and protein system for evaluating cattle diets: II. Carbohydrate and protein availability. Journal of Animal Science, v.70, n.11, p.35623577, 1992. 
STATISTICAL ANALYSIS SYSTEM. User's guide. Cary: SAS Institute, 2002. 525p.

SOUSA, V.L.S; ALMEIDA, R; SILVA, D.F.F.S; PIEKARKI, P.R.B; JESUS, C.P. Effects of partial replacement of soybean meal by protected urea on milk yield and composition. Arquivo Brasileiro de Medicina veterinária e Zootecnia, v.62, n.6, p.1415-1422, 2010.

VALADARES, R.F.D.; BRODERICK, G.A.; VALADARES FILHO, S.C.

CLAYTON, M.K. Effect of replacing alfalfa silage with high moisture corn on ruminal protein synthesis estimated from excretion of total purine derivatives. Journal of Dairy Science, v.82, n.12, p.2686-2699, 1999.

Van SOEST, P.J. Nutricional ecology of the ruminant. 2.ed. Ithaca: Cornell University Press, 1994. 476p.
VASCONCELOS, A.M.; LEÃO, M.I.; VALADARES FILHO, S.C. Ruminal parameters, nitrogen compound balance and microbial production in dairy cows fed soybeans and their by-products.

Revista Brasileira de Zootecnia, v.39, n.2, p.425-433, 2010.

VERBIC, J.; CHEN, X.B.; MACLEOD, N.A.; ØRSKOV, E.R. Excretion of purine derivatives by ruminants. Effect of microbial nucleic acid infusion on purine derivative excretion by steers. Journal of Agricultural Science, v.114, n.3, p.243-248, 1990.

Data de recebimento: 08/07/2013

Data de aprovação: 21/02/2014 